\title{
The Land Use Change From Agricultural to Non-Agricultural in Bungo Regency, Jambi Province, Indonesia
}

\author{
Fajar Ifan Dolly ${ }^{1}$, Kismartini Kismartini ${ }^{1,2}$, Hartuti Purnaweni ${ }^{1,2^{*}}$ \\ ${ }^{1}$ Master Program of Public Administration, Faculty of Social Science and Political Science, Diponegoro University \\ ${ }^{2}$ EDP ${ }^{2}$ Master and Doctorate Program of Environmental Science, School of Postgraduate Studies, Diponegoro Univers ity, Semarang \\ 50241
}

\begin{abstract}
This study aimed at observing the development of agricultural land use in Bungo Regency, Jambi Province, for other purposes, such as plantation, mining, and other commercial buildings. According to the sustainable agriculture supposed by the government, a change in land use has become an important issue to be taken into account as such that the change does not tend to damage the environment. The research findings from Bungo Regency demonstrated the change in agricultural land into copra and rubber plantation areas. Local people had changed their mindset towards reluctance to become farmers, which caused the loss of farmer regeneration and weakened the farmer exchange rate towards the agricultural commodities.
\end{abstract}

\section{Introduction}

Although many forest area have been converted into agricultural land [1], but the opposite in which change in agricultural land use is a practice frequently occurred in many parts of Indonesia, such as in which agricultural land was turned into industrial area [2]. This is despite the fact that agricultural land is crucial for food security in this highly populated country. Therefore, one of the most important issues in today's development is sustainable agriculture. To this end, priority must be put into agricultural land, in particular crop agricultural land for fulfilling the food need. The protection of the sustainable agricultural land closely relates to environmental sustainability [3].

Change in land use, or land conversion, from agricultural to non-agricultural purpose refers to a shift of the land or area from its original use, for agricultural purpose, to other uses, such as mining, building, commercial facility, or settlement. The conversion of agricultural land to non-agriculture is a change of land function or part of what was originally converted into land such as mines, buildings, and shops that resulted in the function of the land to switch the proper function.[4]

Current government under President Joko Widodo has established Nawa Cita (Eight Plans) for development. One of the plan is maintaining sustainable agricultural land. Towards sustainability, the following efforts must be taken: irrigation reconstruction, farmer exchange value improvement, establishment of bank for farmers and small-to-medium enterprise, and acceleration control for the change in agricultural land use. In essence, there must be efforts of maintaining the agricultural land and performing improvement at distribution sectors as well as farmer empowerment programs, and policy improvement. Such efforts are necessary for controlling practices of changing the land use and preserving the food supply at domestic level. According to the data provided by Indonesia Statistic Office (BPS) in 2017 the food needs, such as rice, at the domestic level from January to February reached 14,473 tonnes. The rice were imported from Pakistan, India, Thailand, China, and Vietnam [5].

The government has been making an important effort by establishing a policy on preventing the change in agricultural land use to other purposes through Decree 41/2009 on Protection of Sustainable Agricultural Land. The central and local governments are working in concert to perform the sustainable agricultural practices in simple, self-help, and strong manner towards food resilience and security. The local government is responsible for preventing the conversion of the agricultural land into other purposes, which tend to damage the environmental sustainability.

This study aimed at identifying and analyzing the change in agricultural land use in Bungo Regency, Jambi Province. The study would find out whether the policy on preventing the change in agricultural land use into non-agricultural purposes had been properly implemented.

\section{Methodologies}

This study applied a qualitative methodology in a descriptive analysis. Research informants were selected by a purposive sampling technique. The informants consisted of individuals with adequate and reliable 
knowledge about agriculture and were of the Government Agencies of Bungo Regency, such as Agricultural Affairs, Local Development Plan, Commission II of Local People's Assembly, Environmental Affairs, District Agricultural Extension Staff, and Law Enforcers. In addition, a snowball technique was also applied to gather informants from the local community. This group of informants was represented by a farmer union namely Kelompok Tani Sri Bulan from Tanah Periuk. To analyze the data the study applied a Miles and Huberman model [5].

\section{Result and discussion}

\subsection{Agricultural land in Bungo Regency}

Bungo Regency consists of a terrestrial area with large portions of lowland and marsh. Its soil composition was dominated by andosol, which spreads over areas in the districts of the regency. Andosol is a volcanic soil with fertile quality and contains rich nutrient, suitable for agriculture. In 2010 Bungo Regency covered 15,381 hectares of agricultural area. However, in 2013-2015 period, the Bungo Regency Office of Agriculture and Horticulture reported that the ricefield area had declined as much as $1.03 \%$ (1,105 hectares). Furthermore, the area for vegetables and holticultures also declined as much as $0,8 \%$ (380 hectares). These figures indicated a decrease in the total agricultural area in Bungo Regency [6].

Land use in Bungo Regency was divided into forestry $(35,2 \%)$, rubber, copra, and mix plantation $(34.7 \%)$, rice field agriculture (13.2\%), and settlement $(1.5 \%)$ [7]. The change in agricultural use had become the third greatest change after the change in forestry area into other purposes. The change in agricultural use into other purposes had raised the existence of cultivated plantation for rubber, copra, and mix plants. The distribution of the agricultural land was fairly equal for each district in the regency. Table below describes the agricultural land use for the period of 2010-2015 in Bungo Regency.

Table 1.

Change in Agricultural Land Use in Bungo Regency 2010-2015

\begin{tabular}{|c|c|c|c|c|c|}
\hline \multirow[t]{2}{*}{ No } & \multirow[t]{2}{*}{ Year } & \multicolumn{3}{|c|}{ Description } & \multirow{2}{*}{$\begin{array}{l}\text { Total } \\
\text { (Ha) }\end{array}$} \\
\hline & & $\begin{array}{l}\text { Rice field } \\
\text { and } \\
\text { plantation } \\
\text { (Ha) }\end{array}$ & $\begin{array}{c}\text { Secondary } \\
\text { crops } \\
\text { (Palawija) } \\
\text { (Ha) }\end{array}$ & $\begin{array}{c}\text { Horticulture } \\
\text { (Ha) }\end{array}$ & \\
\hline 1 & 2 & 3 & 4 & 5 & 6 \\
\hline 1 & 2010 & 12,553 & 1,756 & 1,009 & 15,381 \\
\hline 2 & 2011 & 12,666 & 1,432 & 988 & 15,086 \\
\hline 3 & 2012 & 11,807 & 1,201 & 1,045 & 12,972 \\
\hline 4 & 2013 & 8,123 & 887 & 1,097 & 10,107 \\
\hline 5 & 2014 & 10,689 & 1,459 & 1,869 & 13,917 \\
\hline 6 & 2015 & 8,830 & 1,967 & 1,068 & 11,865 \\
\hline
\end{tabular}

Source: Bungo Regency Office of Agriculture, Food Crops, and Horticulture (Bungo.co.id)

The above table explains the diminishing rice field area over time. The dramatic decline occurred in the span of three years from 2010 to 2013, reaching 6.5 per cent and affecting 8,569-hectare area. Such phenomenon was caused by much lower rice field economic value than that of for other purposes. However, in 2014 there was an increase of agricultural area up to 1.5 per cent, in particular that of horticulture crops (2.2 per cent). The increase, unfortunately, was only temporary because in 2015 the agricultural area continued to decline. In other words, the rate ratio between agricultural use and other uses was dynamic and dependent upon economic and commodity values.

\section{a. Policy}

At national level, the National Land Office (Badan Pertanahan Nasional) has recommended a policy on controlling the rice field conversion under three zoning criteria, i.e.: (1) rice field eligible for conversion; (2) rice field eligible for restricted conversion; and (3) rice field ineligible for conversion (protected zone) [8]. To control the agricultural land conversion practice the government has issued Law 41/2009 on Protection for Sustainable Food Crops Agricultural Land. This law is expected to enhance the availability of the agricultural land for food selffulfillment, resilience, and security. The Law 41/2009 has objectives as follows: (a) to perform a sustainable protection of the agricultural area and land; (b) to secure a sustainable food crop agricultural land; (c) to provide food self-fulfillment, resilience, and security; (d) to protect farmers' agricultural land tenure; (e) to improve farmers and community welfare and prosperity; (f) to improve protection and empowerment of the farmers; (g) to increase more job opportunities for happier life; (h) to maintain ecological equilibrium; and (i) to create agricultural revitalization. 
Because of its fertile agricultural land Jambi Province has a potential to be a center for food supply in 2025. It is going to be a disaster if the changes in agricultural use into plantation, industrial sites, and mining continue to happen. The Provincial Government of Jambi has therefore ratified the Law 41/2009 by establishing a policy on rice field conversion control through Governoral Decree 14/2009 on Prevention of Food Crop and Horticulture Land Conversion for Other Purposes in Jambi Province. This decree has major objectives as the followings: (a) to implement sophisticated, self-dependent, and resilient agriculture to support food and horticulture security using sustainable food crop and horticulture lands; and (b) to prevent the change in food crop and horticulture land use into other purposes to maintain sustainable agriculture. However, the conversion practices have been continuing to grow.

In order to prevent the change in agricultural land use in Bungo Regency the local government, following the Law 41/2009 and the Governoral Decree 14/2009, has established the Regency Decree 7/2014 on Protection of Sustainable Food Crop Agricultural Land. Unfortunately, this decree has not been supported by technical guidance for its implementation by the Bungo Regency Office of Agriculture. Accordingly, the prevention of the change in agricultural land use into other purposes in Bungo Regency is finding a deadlock.

A series of complementary regulations have also been put in practice from the central to the local levels. However, the practice of changing the agricultural land use has not been immediately prevented, making it difficult to obtain the dream of being a center for food supply. In practice, the change in agricultural land use closely relates to the economic needs. Most of local people tend to pursue more promising land uses than merely agriculture [9].

A series of activities related to the change in agricultural land use have caused the local people to have more motivation to cultivate copra and rubber. The increasing plantation area in some regencies in Jambi are motivated by the higher price of copra and rubber commodities. Compared to other agricultural commodities, copra and rubber are considered to give more benefits in terms of cash income, either periodically or immediately [8]. To the date, 10,000hectare agricultural land has been changed into copra and rubber plantation, settlement, and rural gold mining, all without license. When this trend continues, rice supply from the rice field for Jambi is going to decrease over time [10].

Studies have shown that the change in agricultural land use into copra plantation may cause misery in the long term because it affects multiple aspects, i.e. ecology, social and culture, land and resource conflicts, environmental pollution, and food scarcity [11].

Local people of Bungo Regency has been practicing the change in agricultural land use for generations. Such practice is complicated because it involves various actors in interest. In the long term, the change in agricultural land use into other purposes will threaten the food security. Indeed, another problem arises for the low farmer exchange value for production so that most of the farmers tend to be hopeless in cultivating their land. Lacking infrastructure maintenance is also problematic because it relates to maintenance cost. The irrigation system is inadequate so that it is too vulnerable towards natural climate and climate change.

The Bungo Regency Government has not been responsive to opinions, discussions, and inputs from the rural people concerning problems they face in their agricultural activities. Agricultural extension is inadequate so that knowledge and technological exchange do not take place, causing the delay of the agricultural production process.

\section{Conclusion}

Summaries : (1) Change in agricultural land use into copra and rubber plantation in Bungo Regency still frequently occurred; (2) Change in agricultural land use has threatened long-term food security along with inevitable demographic bonus; (3) Change in agricultural land use into other purposes has caused losses. Many negative impacts have been experienced by either community or environment; (4) Change in agricultural land use involves many actors of interest, such as local people, civil society, business community/persons, and the farmers.

Recommendation: (1) Change in agricultural land use into other purposes in Bungo Regency can be prevented by intensive co-operation and coordination between stakeholders; (2) To minimize the further opening of the rubber and copra plantation a special team is necessary to be established to secure the sustainable agricultural land by determining limitation of the area eligible for the plantation; (3) The local government of Bungo Regency must develop a co-operation with rural officials, traditional organs, agricultural academics, nongovernmental organizations, environmentalists, and local leaders to prevent the change in agricultural land use; (4) The local government of Bungo Regency must give legal protection to all villages and rural officials who implement regulations and punishment according to local tradition to those who perform the illegal change in agricultural land use.

\section{References}

1. A.Mufubi, Y.Setiawan, H.Effendi, Procedia Environment Sciences 33 (2016), 654-660.

2. P.A. Permatasari, A.Fatikhunnada, Liyantono, Y.Setiawan, Syartinilia, A.Nurdiana, Procedia Environment Sciences 33 (2016) 27-35.

3. MF. Anita.W.Handari, AN. Bambang, H. Purnaweni, Ekosains, (2012), Vol 4 (3), pp 19-26 
4. Rustiadi, Ernan dkk, 2012, Penyelamatan, Tanah, Air dan Lingkungan, Crespent Press, Jakarta.

5. Detik Finance, Kamis 16 Mar 2017. https://finance.detik.com/berita-ekonomibisnis/3448448/ri-impor-beras-di-awal-tahun2017-paling-banyak-dari-pakistan

6. Bungo Dalam Angka, 2015. Badan Pusat Statistik Kabupaten Bungo, Jambi (2015)

7. Suryani, Lili, Analisis perubahan penggunaan lahan, komoditas unggulan perkebunan dan arahan pengembangannya di Kabupaten Bungo, Provinsi Jambi

http://repository.ipb.ac.id/handle/123456789/7879 6. (2015)

8. Minsyah, Endrizal, dkk, 2012, http://www.litbang.pertanian.go.id/buku/konversifragmentasi-lahan/BAB-IV-3.pdf
9. Puspasari, Anneke, Faktor-faktor yang mempengaruhi alih fungsi lahan pertanian dan dampaknya terhadap pendapatan petani (studi kasus Desa Kondangjaya, Kecamatan Karawang Timur, Kabupaten Karawang), Tesis IPB, Bogor. (2012)

10. Suara Pembaruan, 26 Februari 2015. http://sp.beritasatu.com/ekonomidanbisnis/jambiberi-sanksi-pada-pelaku-alih-fungsi-lahantanaman-pangan/79382.

11. Herman, Fahmuddin Agus, dan Irsal Las, Analisis finansial dan keuntungan yang hilang dari pengurangan emisi karbon dioksida pada perkebunan kelapa sawit, http://pustaka.litbang.pertanian.go.id/publikasi/p32 84092.pdf (2009) 